\title{
O RUMOR DA LÍNGUA DE MARCOS SISCAR
}

\author{
Milena Magalhães \\ milena_guidio@yahoo.com.br
}

Livro do silêncio

Sussurrar pode ser um descanso do rumoroso mundo

das palavras.

In: O livro de cabeceira, Peter Greenaway

1.

“... O simples ato de escrever já destoa da virtude e da modéstia do silêncio..." (SISCAR, 2012, p. 27). Essa frase, de um dos textos do poeta, crítico, professor e tradutor Marcos Siscar, posta entre reticências, à espera da prova de seus sentidos, diz muito sobre sua trajetória naquilo que envolve seu corpo e corpus. Sua escrita - tanto poética como crítica - constitui uma poderosa experiência sobre o dizer que reelabora as demarcações de quem está na posição de dizer e de questionar os dizeres, possibilitando uma discussão sobre o ter lugar da poesia. Sem poder ser chamado de poeta bissexto, ele publica pouco. Metade da arte surgiu em 2003, reunindo sua obra até então; O roubo do silêncio em 2006; e Interior via satélite em 2010. Entretanto, reelaborar a "ficção de origem e de destino" desse poeta não é uma tarefa das mais fáceis. Como ele sugere em um de seus poemas, a origem "começa no fim" (2006, p. 31), rompendo a causalidade da antinomia. Suas investigações, se não possibilitam identificar a origem, uma vez que se trata justamente de instituí-la como ficção, permitem perscrutar os rastros que se espraiam por sua poética, 
afirmando, de imediato, que ele tem o que dizer sobre o que diz. Quando diz. O lugar do poeta.

No sentido mais imediato de uma primeira tentativa de interpretação da citação, soberba e barulho se relacionariam com o ato de escrever, mas é preciso modular os sentidos dessa relação e não transformar a poesia no lugar do hermetismo e do afastamento do solo do real. Essa é a tomada de posição, por exemplo, de Jacques Rancière (2012, p. 106) quando se refere a Mallarmé e às alusões constantes de ser ele o "poeta noturno do silêncio e do impossível". Rancière relembra a necessidade de considerar o contexto das reivindicações do poeta francês, contrariando as leituras que o isolam em uma redoma esteticista. Ao enfatizar que há uma superfície comum das "formas", que servem tanto ao poeta quanto a um uso "funcionalista", o filósofo estabelece uma relação imprevista do poeta com as questões de seu tempo que servem à averiguação do lugar político da poesia. Não é outra a discussão que Siscar trava no ensaio Soberba da poesia: distinção, elitismo, democracia, de onde foi retirada a citação referida no início. Nesse ensaio, duas cenas de "soberba" servem de exemplares para Siscar expor as razões por que o poeta reivindica a sua soberania. Segundo ele, estas não se relacionam com um estatuto de direito, "uma condição a ser protegida como tal”, mas, sim, com um "desafio" lançado ao que não está garantido por falta de definição e que, por isso mesmo, deveria ser recomposto na iminência da perda (2012a, p. 61). Nesse texto, Siscar contra-argumenta os discursos que reconhecem na poesia o afastamento do político, por meio de um posicionamento que estaria acima das questões sociais ou de costas para elas. Para ele, pelo contrário, a poesia constrói as suas próprias formulações a respeito do discurso da crise, dando-lhe respostas que são tanto um enfrentamento às injunções exteriores, quanto um desdobramento de suas questões intrínsecas.

Constituindo ele mesmo uma cena de leitura, comum em sua ensaística e seguindo sua investigação acerca da difícil relação dos sentidos da poesia, Siscar afirma que a experiência moderna de Mallarmé com o poema "Um lance de dados" apontaria para um discurso das "alturas" que se sustenta na sua relação com o chão, a queda. Em suas palavras, "A altura não nos garante exatamente um patamar panorâmico sobre o qual teríamos a prerrogativa (estética) do sentido da totalidade; ela está sempre na iminência do chão, porque é dele e em relação a ele que se distingue, e vice-versa." (SISCAR, 2012a, p. 65, grifos do autor). O ato de escrever, e escrever poemas, nos quais se configura certo tudo-dizer, 
reporta-se à soberba em um sentido mais intrigante e, por isso mesmo, mais desafiador ou contrariante: é de um "lugar de falha" que se diz o que se tem a dizer. E justamente porque se pode tudo dizer, pode-se preferir não dizer.

Há nos enfrentamentos críticos desse autor, marcados geralmente pela insistência de apresentar outras possibilidades às leituras cristalizadas ou prestes a cristalizarem-se, como as que envolvem Mallarmé ou a situação vivenciada por Nuno Ramos - inquirida por ele no ensaio citado -, respostas que interrogam zonas de silêncio no interior dos discursos. Desse modo, o ato de escrever destoaria da virtude e da modéstia do silêncio, justamente porque arrebataria o silêncio da sua condição, fazendo-o falar ou, ainda, frustrar os sentidos já agregados, contrariando o que vem à tona, ou seja, o silêncio.

Devido a esses sentidos, que ligam a experiência do dizer à opacidade do silêncio, valho-me da expressão "rumor da língua", emprestada de Roland Barthes, para que eu nomeie a experiência poética intentada por Siscar. Não há na minha apropriação uma rigidez nas acepções críticas que se podem extrair desse texto de Barthes (2004). Interesso-me mais por aquilo que, com certa liberdade interpretativa, esse texto me induz a perceber nos dizeres sobre "o silêncio dessa poética: não propriamente" o silêncio, mas o que está em seus limites; não necessariamente o seu oposto (fala, barulho, alarido, gritaria), mas o que fica no entremeio: o sussurro, o ciciar das palavras. Ou, na expressão de Barthes: o rumor da língua. Os ditos que agregam os não-ditos criam um ritmo descontínuo, instalando uma atmosfera de segredo que rumoreja, isto é, que busca certa dicção, certo tom na composição dos poemas, que, a meu ver, não se prestam à leitura em voz alta, justamente porque instauram um tom que demanda uma espécie de sussurro. Os procedimentos formais do acúmulo de palavras, do corte, da cesura da sintaxe, da interrupção da frase, comuns em sua poesia, levam-nos, antes, ao gaguejar, mais próximo do balbucio. Entrevejo aí a materialidade da sua política de reflexão acerca dos lugares comuns que cercam o discurso crítico sobre a poesia. Como na epígrafe deste texto, "sussurrar pode ser um descanso do rumoroso mundo das palavras” (GREENAWAY, 1996).

Indo mais adiante na proposição do título, com essa apropriação, gostaria de insinuar que há uma "língua" em/de Marcos Siscar. Para ser mais exata, há a instalação de uma linguagem que, embora estabeleça diferenças em cada livro publicado, permite o seu reconhecimento. As 
zonas de silêncios que se instalam ultrapassam o fato de o silêncio constituir-se como um de seus temas. As perífrases, em seus volteios, conjugam ao seu redor palavras-quase-silêncio. Em poemas como os reunidos em Metade da arte, "Esfinge sem pergunta", “Túmulo de Ícaro", "o silêncio chega sempre de surpresa de dentro / das coisas que se olham esquecendo que se vê...., a exemplo deste, sem título, em Interior via satélite (2010a, p.97).

Quando Barthes pensou no rumor da língua não incluiu a poesia; pelo contrário, afirma a Poesia - com letra maiúscula - como o lugar em que a "música dos fonemas" é apenas o "fundo", enquanto ele prediz que o rumor da língua relaciona-se com uma utópica "música do sentido" na qual "a língua seria ampliada, eu diria mesmo desnaturada, até formar uma imensa trama sonora em que o aparelho semântico se acharia irrealizado;...” (BARTHES, 2004, p. 95). Para além da desqualificação da poesia e do vocabulário estruturalista de que se vale Barthes nesse texto, a desnaturalização do sentido, que não chega à abdicação como ele preconiza, certamente não é estranha aos procedimentos adotados por Siscar. Na rede de silêncios que envolve o corpo dos poemas, ouvimos uma certa relação com a língua da poesia que não é da ordem da explicitação das possibilidades sonoras e semânticas, mas da resistência de fazer da palavra mero conceito. Também aí é possível pensar em Barthes, que defende uma utopia do sentido justamente onde este se apresenta como falta, insinuando que onde há demasiado sentido não pode haver "gozo" na linguagem, cabendo ao rumor da língua produzir o "impossível”, esse "próprio" da linguagem, nomeado por ele de "gozo", que não abdica dos sentidos, mas desorienta-os, destinando-os de maneira incerta. Assim, o rumorejar, contrário ao barulho maciço da "massa" (diríamos, hoje, da multidão), constitui uma erótica, uma paixão da língua que interroga incessantemente os sentidos, fazendo-os estremecer, retirando-os da sua natureza de corpos que dizem. Antes, as palavras em delírio. Desde o primeiro poema de Metade da arte, essas questões já estão postas. A escolha das palavras (e não de outras), o fluxo interrompido, o endereçamento ao outro, a voz que não sobra; tudo se acumula em cenas de paixão, constituindo a experiência do rumor que rompe com o "pacto de silêncio". Não é propriamente o dizer, e sim a promessa do dizer:

Diante de si estas palavras e não outras/ a boca disse e dirá e não terá sido pouca/ palavra sequer a sua não há conserto ou/ festa apenas você isso muito me espanta/ e o coração sem memória desperta/ para o que não se deu ora 
tudo/ que não se deu se pode dizer dizer não/ se faz com fatos ah alegria da negação/ todas as vezes que morri pergunte ao pó/ o que direi se da sua voz não sobra/ nada senão a atenção do gesto o corte/ um ícone de privação do fluxo enquanto/ olhos inundados por humores de urina/ virão romper o nosso pacto de silêncio/ e então meus braços farão o nó da/ proximidade aflita diga quantas vezes/ sua boca me destilou delírios quantas/ vezes um gemido nos salvou um mundo (SISCAR, 2003, p. 8).

A repetição de formas derivadas de dizer, que culminam, no fim do poema, em delírios e gemido, isto é, em gozo, reverbera, ainda, no que Barthes (2004, p. 94) aponta: "Porque o rumor (...) implica uma comunidade de corpos: nos ruídos do prazer que 'funciona', nenhuma voz se eleva, conduz ou se afasta, nenhuma voz se constitui; o rumor é o próprio ruído do gozo plural - mas de nenhum modo maciço”. As inquirições em torno do dizer apresentam-se também como formas atormentadas de interrogar o não-dito ("proximidade aflita"), fazendo com que a promessa de romper o pacto de silêncio seja continuamente adiada para um porvir. É uma intimidade que se esboça. O sujeito não está só, dirige-se a outro e com esse outro estabelece uma relação, faz um corpo ser comum a outro. Trata-se de uma cena de paixão, de uma erótica do rumor, no poema, diante do poema ("diante de si"); trata-se também do coração, do "coração sem memória”.

No poema "Livro", de Interior via satélite, também o corpo está em contato com outro corpo: "a paixão pelo teatro nu sobre o qual se incendeiam as carnes do mundo. o corpo só sensível eriçado ao contato com o outro corpo" (2010a, p. 57). O título antecipa a cena metalinguística, e o "livro carrapicho", com seu corpo eriçado, remete à herança deixada por Mallarmé. Os vocábulos, espraiados ao longo do poema, em um jogo extratextual e metalinguístico explícito, lançam-se tanto para o próprio fazer quanto para a herança que possibilita o fazer. É uma cena de identificação, na qual se define o livro que se deseja (o verbo "quero" na primeira frase já cria a cena de desejo) e também a recepção que lhe deveria ser ofertada. Não é "o peso da mão" nem "a concha da mão" que se interpela na feitura do livro; não é a força da interpretação, no sentido bíblico, que se almeja'; é justamente o contrário. No poema está dito expressamente: "a matéria pedindo não o peso da mão não a concha da

${ }^{1} \mathrm{Na}$ Bíblia, Isaías (capítulo 40, versículo 12) interpela: "Quem mediu com a concha das mãos as águas, ou tomou a medida dos céus aos palmos? Quem recolheu numa medida o pó da terra? Ou pesou os montes e os outeiros em balanças?"(1999, p. 649), de maneira a não haver margens a interpretações que levem a outro nome que não o do Senhor. 
mão mas o toque da mão que renomeasse que redispusesse o mundo por resistir-lhe. e ainda assim um livro. um livro de fogo". (idem). Não é a força da lei. Imagens como "livro carrapicho", "alfaia das vísceras", "leve como um náufrago", “coração a nu”, "lustre da audácia”, dentre outras, de maneiras distintas, se prolongam em outros poemas de Siscar, tornando-se parte de seu corpus como imagens herdadas; no caso, a herança ostentada de Mallarmé e seu livro por vir. Por outro lado, as injunções do poema parecem dizer respeito também ao seu criador: "meu livro de carne dura. infenso às ondas do bom senso. aos delírios da boa-fé. às palavras muito exatas. em suma ao narcisismo sem náusea." (2010a, p. 57). O poema lança uma aposta ao enumerar seus interditos, mas sabendo que, no fundo, não pode evitá-los. No "livro de fogo", muita coisa desapareceu, foi incinerada antes de constituir-se como marca. Ainda é a mesma questão do primeiro poema de Metade da arte: a soberba do envio vem acompanhada da dúvida de seu alcance. Disseminando imagens célebres de Mallarmé, o poema aponta para os limites de sua audácia. Não se trata, portanto, tão somente de uma questão de herança, mas do modo como essa herança responde às questões que são próprias de sua poesia.

Essa maneira peculiar como Siscar responde a sua herança francesa se estabelece desde Metade da arte. Esse título-que-advém-da-frase, extraído do dizer célebre de Charles Baudelaire, estende-se à epígrafe do livro: “... le transitoire, le fugitif, le contingent, la moitié de l'art”...", com o uso das reticências cortando ao meio o sentido da frase de Baudelaire. Instaura-se, assim, logo na abertura, um diálogo incompleto, a refazer-se no corpo dos poemas, mas que indica não haver filiação sem a mediação das diferenças. A instauração de outros espaços, além do citadino, não deixa de virar as costas à certa banalização da ideia de cidade, de "poesia urbana", que foi tantas vezes reiterada a partir da herança do poeta francês. As imagens do exterior, em Siscar, não remetem à figura de um flâneur errante pelos escombros de uma modernidade perdida. O exterior em seu sentido literal configura-se como seu contrário, pois não se trata de paisagens das cidades-metrópoles. São paisagens do interior, provincianas, em que se disseminam rios, estradas etc.., mas também variadas visões da espacialidade, como no poema "Turismo interno", no qual os primeiros versos são imagens do limiar: "alguns desciam do ônibus iam a pé para suas casas. outros perto da janela consultavam em cadernos antigas anotações quase ilegíveis" (2010a, p. 34). Esses espaços liminares criam a indecisão do que seja interior/ exterior, dentro/ fora, acrescendo-se ainda 
a perspectiva do alto/ baixo, próximo/ distante: "do alto a terra é uma colcha de retalho costurada pelos rios... o poema é o ponto que suspende esse tecido/ que edifica em torno o vazio que dá abrigo/ à urgência da terra e à possibilidade / de perder-se nas encruzilhadas". (idem, p. 24).

\section{2.}

Em depoimento à Remate de Males, no qual precisa responder à enquete "Por que escreve", Siscar relança, mais uma vez, a questão da alteridade, fazendo-se leitor de si mesmo, como "um carroceiro [que] deve preparar o terreno". Entretanto, há aí o enfrentamento do cálculo imprevisível da resposta, configurando-se ela mesma por rodeios em torno de uma questão aparentemente singela. Assim, embora faça as vezes de crítico de seu corpus, até mesmo analisando uma anotação que anuncia o projeto de um livro por vir, ele fustiga o leitor de "hábito cansado de retóricas e astúcias literárias", desafiando-o a reconhecer o poema como o lugar da contradição, da contrariedade; o lugar no qual se lança em direção ao outro sem o anseio do denominador comum. Quando uma pergunta é lançada, ou um poema é escrito, ou um terreno é "preparado", tem início o seu processo de arquivamento. Porém, não se pode requerer do poema que diga tudo, tampouco a ausência de uma singularidade que pode ser desconsiderada. O trabalho de repetição nessa poesia tem a ver com o duplo movimento: no arquivamento, deve-se considerar o que ele comporta de segredo, o que não se deixa dominar pela generalidade do gênero, porém deve-se estar atento ao que retorna incessantemente como um fantasma em busca de alguma retratação possível.

Marcos indaga sobre o que significa para o escritor estar na posição de ter que responder, quando estão em jogo questões de afeto, de relação narcísica com a própria história, de reconstituição do percurso. No depoimento que deveria ser um testemunho de suas razões, como se fosse possível nomeá-las de maneira inequívoca, testemunha-se, de fato, a violência do próprio testemunho, apontando a relação deste com a lei, o dever, a responsabilidade, que nos remete à proximidade com os ditames da inquisição, do interrogatório. Isso se dá, talvez, porque há no seu trabalho uma reserva em relação à ordenação dos discursos que indicam os lugares de fala do escritor. Há setores da crítica - e mesmo entre escritores - que ordenam que o autor se cale, tamanha a imagem 
cada vez mais cristalizada que relaciona o escritor contemporâneo a uma visibilidade ostensiva, como sendo aquele que se exibe de maneira incondicional à exposição pública. Essa imagem, ao ser constituída e reiterada, não ordena senão - como se faz com as crianças, a quem desde cedo é inculcada a virtude do silêncio - que o escritor se cale, atacando-o em sua fragilidade aparente. A violência das injunções, para Siscar, pode ser contraposta pela disposição de não se sentir obrigado a responder a todas as demandas. Isto é, um jeito de não se sentir tentado ao alarido ininterrupto da presença. A posição de enfrentamento do silêncio passa pela possibilidade de dizer não ou, pelo menos, fazer com que o sim seja "atravessado", acrescentando-se modos de dizer, de maneira a não se deixar ver sem antes imprimir uma assinatura, ao que, depois de dito, estará à disposição do leitor, do crítico; enfim, do barulho do mundo: "A poesia é para mim o nome deste lugar onde uma resposta atravessada se permite. (...) Tenho minhas razões, públicas e privadas, para preferir que a resposta esteja sempre atravessada, muita vezes na garganta" (2010b, p. 245, grifos do autor).

Uma resposta atravessada na garganta é aquela que quer sair e, muitas vezes, não sai por um sem-fim de razões, assemelhando-se a um gesto de silêncio contrariado; pode ser uma resposta que quer ser dada, mas permanece como possibilidade que foi barrada. Por outro lado, como o próprio Siscar relaciona no mesmo texto, talvez faça parte da abertura proporcionada por Bartleby, de Melville, simplesmente preferir não responder ${ }^{2}$. Caberia ao poeta contemporâneo optar por uma espécie de silêncio que não se deixaria emparedar, como Bartebly, com o poema sendo o lugar em que se investigam formas de silêncio que evaporam o "barulho do mundo" (ainda uma expressão de Barthes), a partir da investigação própria de seu dizer. No poema "Psicanálise caseira", a constatação de que há sobras, tanto no não-dito como no dito, gera um questionamento antitético que se abre para a possibilidade de haver alegria justamente nos restos dos dizeres, quando se apela para o outro suplementar a miséria da escassez das palavras: "há coisas de sobra que não se dizem/há coisas que sobram no que se diz/nossa miséria é uma alegria de palavras?” (SISCAR, 2003, p. 69).

\footnotetext{
${ }^{2}$ Ainda na especulação das razões da pergunta "Por que escreve", Siscar diz: "No fundo, a tradição aberta por Bartleby, de Melville, com sua célebre resposta 'I would prefer no to' (preferiria não, preferiria que não), acabaria dando um viés bastante estimulante para interagir com o "por quê?" alienígena: preferiria não responder" (2010b, p. 242-243)
} 
As sobras estão, por um lado, ligadas à escassez e, por outro, ao transbordamento, ao excesso. Esse é o procedimento de muitos de seus poemas, nos quais as marcas da hesitação, advindas do corte e da repetição das palavras, adiam os sentidos, deixando-os como promessa. As imagens que circulam, os versos que se repetem, acrescentam dobras às aporias que se constituem por intermédio de um vocabulário da falta, do mínimo: silêncio, segredo, restos, morte, perda. Estranhamente, os acréscimos funcionam como subtração. $\mathrm{O}$ efeito de prolongamento nos poemas, constituído por essas retomadas, presta-se ao diálogo contrariante que se mantém com o leitor. Quando uma figura, que pode ser "coração", "carrapicho", dentre outras, retorna ao poema, acrescemse outros sentidos, que podem tanto confirmar quanto contrariar os anteriores. O leitor constituído pelo texto, portanto, é aquele que aprende a voltar atrás e a julgar que qualquer antecipação está sujeita à falha, pois, na materialidade mesma das palavras, instala-se a falta, expondo a precariedade da recepção. Em uma leitura anterior, sempre faltará a aparição da figura que retorna posteriormente, assim como, na leitura por vir, a figura que reaparece traz os restos de suas outras aparições. Desse modo, o que se encena com tantos volteios em torno do dizer e não dizer é essa relação precária com o possível destino do poema. O poema resiste à destinação, ao mesmo tempo que se coloca à sua disposição; impõe a dificuldade porque faz desta sua própria condição para não constituir uma interlocução que seja apenas fática ou que diga respeito apenas à relação com seu próprio objeto, numa função autorreferencial.

\section{3.}

No primeiro poema de Metade da arte aludido anteriormente, a erótica do rumor se mistura ao coração sem memória: "e o coração sem memória desperta/ para o que não se deu ora tudo/ que não se deu se pode dizer dizer não" (2003, p. 8). Nos versos finais de "Jardim à francesa", o coração também se destina a outra coisa além do sentir: "meu coração às vezes tropeça projeta uma perna/ sobre a outra/ se interrompe mudo parece/ que pensa" (idem, p. 106). É esse outro uso que eu gostaria de relacionar à dificuldade de interlocução. Antes, importante dizer que Siscar expande os "discursos do coração" em sua ensaística, como Celia Pedrosa (2014) lembra ao tratar sobre a questão do endereçamento na poesia brasileira 
contemporânea. Interessa-me, aqui, principalmente, o texto "O coração transtornado", presente no livro Jacques Derrida: literatura, política e tradução, publicado em 2012. O texto do "coração" alude justamente ao texto do filósofo no qual ele trata de poesia, Che cos'è la poesia?. Valhome, então, de uma dupla cena. Como afirma Siscar, "Derrida (1992) mostra que o coração (coeur) não se dissocia da experiência da repetição e da memória, daquilo que se sabe de cor (par coeur)" (2012, p. 139), o que pode ser outro nome para a experiência da leitura, na qual se investiga o que está dentro do poema, fazendo-se o movimento de buscar fora dele. Em outras palavras, uma leitura que não se queira ingênua não prescinde de um arquivo de referências. Como o texto sugere, a travessia do poema pode ser catastrófica porque se endereça a qualquer um, põe-se sob o risco do outro anônimo. Assim, requerer um aprendizado "de cor" do poema é, de certo modo, circunscrever de uma maneira sempre incompleta modos de recepção. Nesse sentido, aprender "de cor" seria mais do que decorar; seria olhar atentamente o poema, atentar para seus detalhes, até encontrar o tom que permita falar dele de memória (há aí toda uma dicção da memória). Saber de cor seria, portanto, deixar-se afetar pelo poema, seria repeti-lo de outro modo; não de modo parafrásico, mas, sim, pensante, pois o coração pensa, parece que pensa, como sugere "Jardim à francesa".

Em texto sobre Ana Cristina César, Siscar reconhece que trânsito é uma "palavra gasta", expressão que também é o título de um de seus poemas, mas para ele faz sentido pensá-la para traduzir a estratégia da poeta na composição de sua retórica da interlocução, constituída por um incessante endereçamento ao outro, tocando na materialidade dos poemas o problema da destinação, na medida em que "obsessivamente destina-se a ele, requisita sua participação, dá-lhe a vez" (2011, p. 39). Para além das diferenças entre os dois, assinaladas tanto por Annita Malufe (2011) como por Celia Pedrosa (2014), Siscar alude nesse texto a questões que dizem respeito também à sua poesia. A destinação incerta - como todo envio - realiza uma travessia que põe em jogo a singularidade do sujeito à mercê de uma idealidade esboçada no corpo dos poemas.

"Coração sem memória" também estabelece outro modo oblíquo de dicção, uma vez que não se trata de falar do "fundo do coração", remetendo-o de imediato à generalidade dos dizeres sobre o coração (o sentir, o sofrer, o sacrifício). Ao mencionar essa figura tão comum na história da poesia, o poema intenta, de fato, subtrair o arquivo do coração ao lhe dar o qualificativo de "sem memória". Há uma "economia da memória" 
própria da poesia. Para Derrida, em Che cos’è la poesia?, a identidade do poema passa por sua brevidade: "um poema deve ser breve, elíptico por vocação, qualquer que seja sua extensão objetiva ou aparente” (2001, p.113)3. E, em seguida, estabelece como premissa que o coração ("coeur") de que trata a poesia não deve confundir-se com "o coração dos arquivos cardiográficos, simplesmente, objeto de conhecimentos ou de técnicas, de filosofias e de discursos bio-ético-jurídicos. Não o coração das Escrituras ou de Pascal, provavelmente, nem mesmo, o que é ainda menos evidente, aquele que Heidegger prefere ver em seu lugar." (idem). A injunção para esquecer os arquivos do coração, para suspender a memória, enfim, para renunciar ao saber põe o sujeito sob suspeita "desde a origem", pois ao dizer "coração" um sem-fim de imagens prolifera. Como, então, barrarlhe os sentidos? "e o coração sem memória desperta para o que não se deu ora tudo / que não se deu se pode dizer..." (SISCAR, 2003, p. 8), mas o que ainda não se deu é a questão que vai de um transporte a outro. Estamos, portanto, no coração de questões fundamentais para a poesia desde a modernidade, embora a reflexão de Derrida pareça estar na contramão do ideário dos vínculos autorreferencial e intertextual da poesia moderna, expandidos pela contemporaneidade. Para ele, não se trata de pensar a poesia de modo geral; trata-se do poema e da possibilidade de "desfigurar o seu porto", imagem que se liga à "desmobilização da cultura”, almejada pelo filósofo. Talvez desmobilizar a cultura faça parte do cultivo de olhar atento ao poema, de reconhecer nele não a ordem do jardim francês, mas a desordem do jardim onde prolifera o carrapicho.

Ao pôr o "coração sem memória" em torno de uma cena de perquirição do dizer, o que está em jogo propriamente no poema não é a questão do derramamento de sentimentalidade, do encontro amoroso e seus possíveis conflitos, mas os modos como se traduz o sujeito que gira em torno do dizer, a partir da figuração de um coração desmemoriado. Siscar assim interpreta o que Derrida (2013, p. 139) afirma: "o coração está ali, mas o que é colocado em questão não é exatamente o sentimento, a vontade, a intuição em si, mas as relações que instauram com aquilo que chamamos origem”. Pode-se, então, ler o poema de Siscar como uma possível tradução do texto de Derrida, desde que se reconheça que se põe em cena também o esquecimento originário, na constituição de um poema "sem memória",

3 Utilizamos aqui a tradução feita por Tatiana Rios e Marcos Siscar, publicada na revista Inimigo rumor n. 10. Editora 7 letras, maio de 2001, Rio de Janeiro - Brasil, p. 113-116. 
na medida em que o leitor pode prescindir dela. Isto é, oferta-se ao leitor apenas a possibilidade, mas não a obrigação de reconstituição da cena.

$\mathrm{O}$ uso da perífrase e do enjambement, duas figuras recorrentes no seu fazer poético, como vários de seus críticos já notaram, é um dos propulsores da dificuldade de reconstituição da origem. Quanto mais gira em torno do dizer/não dizer, quanto mais deixa um verso se completar em outro, mais uma forma poderosa de elipse toma conta do poema. A elipse é a figura na qual se trava a batalha do segredo e do silêncio e, a meu ver, é por meio dela que Siscar não faz de sua poesia um mero conjunto de filosofemas. Qual é a origem da cena? Essa é a ficção que se constrói no interior de seus poemas e não se deixa aprender "de cor", não se presta a ser apreendida pela memória na sua relação com "uma certa exterioridade do autômato", com "as leis da mneumotécnica" (DERRIDA, 2001, p. 115). O poema tenta justamente barrar as oposições do interior e do exterior: "por mais que se tenha os olhos fora a saída fica sempre no interior (jeanmichel alberola) ... você olha pela janela. a janela é um abismo para o olhar. você olha para fora só vê interior" (2010a, p. 43). Ao mesmo tempo que trata de memória, que toca na história - seja da poesia, da filosofia, da própria História -, ele estressa, irrita o poema com a quase ilegibilidade das outras "teses", fazendo do poema um lugar de hipóteses, interditando a recondução do "ouriço ao circo ou ao carrossel da poiesis" (DERRIDA, 2001, p. 115), ao mesmo tempo que demanda que se traduza a esfinge, que a salve do programado.

Traduziria, ainda, essa dupla cena da seguinte maneira: discorrer sobre o coração, ou discorrer simplesmente, no poema, é colocar-se em situação de risco; é arriscar entrar no jogo da repetição no momento mesmo em que se ensina a experiência de ocultar o lastro histórico que escorre pelo poema. Dito de outro modo, entra em ação a difícil tarefa de fechar-se sobre si mesmo, sob o risco do acidente. É bonito quando Derrida lança essa possiblidade a partir da figura do ouriço. O poemaouriço que se enrola sobre si, rente ao chão, modesto, protegendo-se ao mesmo tempo que se expõe aos acidentes da travessia. O ouriço de Siscar possui a forma do carrapicho, figura recorrente em sua poesia. Masé Lemos, ao exprimir-se sobre os modos como esse poeta participa de 
discussões que acontecem na França em torno da situação contemporânea da poesia. A partir de pontos de vista distintos dos desdobramentos dos gestos de Charles Baudelaire, lemos que "Siscar cria sua própria 'flor do mal', o carrapicho, erva daninha sem floração, acentuando desse modo a negatividade da flor baudelairiana, para profanar por sua vez essa flor já tornada relíquia e tentar, ainda por meio desse ato, uma revelação" (2011, p. 31). Essa interpretação é justa e firma-se nas correspondências feitas por Marcos em poemas como "As flores do mal" e "Fenomenologia do carrapicho". Quanto mais tenta extirpar a "flor incisiva", indesejada nos jardins, cuja existência o sujeito lírico atribui a seu silêncio ou a sua omissão, "em uma espécie de autoacusação", mais ela é acolhida pela terra "hospitaleira" de seus poemas, espalhando-se de forma desordenada.

Vistos de cima, tanto o ouriço como o carrapicho possuem "todas as flechas para fora”, ainda usando uma imagem de Derrida (2001, p. 115). A forma do carrapicho é a mesma do ouriço quando se enrola sobre si para se proteger: um "círculo raiado", como o apresenta Siscar no poema "As flores do mal". Seus raios apontam para fora e, embora quem os queira arrancálos arrisque-se à ferida, não estão imunes ao ataque: "Em dias como este, as mãos calejadas de sentido, me ajoelho e o ataco com as unhas. E, no meio de ervas daninhas, suo, me sujo, concentrado como um artesão, enfurecido como um filósofo, a extirpá-lo" (2006, p. 17). Nessa proximidade com o chão, a questão ainda é a do perigo da ferida (o poema-carrapicho) e, concomitantemente, o perigo de expor-se à ferida da dispersão. Aberto, assim, ao risco, o poema intenta proteger-se dos danos, lograr os cálculos prévios da leitura. No poema "O espelho da pele", como uma extensão do final de "Fenomenologia do carrapicho" (“Já não me lembro como o evitava, na época dos pés descalços. Talvez não o evitasse” - 2006, p. 18), a paisagem constituída é a da infância livre do medo das feridas:

\section{O ESPELHO DA PELE}

A criança corria sobre palha seca e carrapicho. Corria e caía não distinguia o que fosse o tempo e o que fosse o dano. Não se interpunha tão cedo o cálculo interminável dos vãos benefícios. As feridas fechavam e nem as cicatrizes eram feitas para tantos anos apenas o ônus e de novo a pele lisa. A carne e a regeneração eram como o campo de milho e a erva daninha a unha e a carne o que hoje nos parece uma milagrosa sinonímia. E eis que mesmo a palha e o carrapicho vinham de dentro saíam inteiros de antigas feridas já curadas pelo tempo. O corpo os expulsava com uma emulsão esbranquiçada escorrendo pela 
perna como se atravessassem o espelho da pele a cicatriz de superfície elástica e lisa e do prodígio nos restasse apenas isso ${ }^{4}$.

Precipitando uma síntese, diria que, aqui, o fora e o dentro não se divisam. O círculo raiado que é o carrapicho, cuja presença de fora pode afetar o sujeito e ser afetado por ele, vem de dentro, atravessa "o espelho da pele". A "ficção de origem" posta em cena aponta para a relação intempestiva da leitura do que já-foi (o passado das feridas), mas continua incessantemente a fazer-se presente. A situação assemelha-se com a série de azulejarias em carne viva, as paredes com incisões à la Fontana ou, ainda, as ruínas de charque, de Adriana Varejão ${ }^{5}$, em que o interior das feridas avança para fora. A superfície é a própria ferida, expondo quem a contempla ao ferimento. Em suma, os poemas são marcados por essa outra presença, e, com ela, põem à prova a sua possibilidade de se fazerem poemas, pois no que é possível traduzir no discurso algo poético de Derrida, em Che cosè la poesia? e na dramatização operada por Siscar em muitos de seus poemas, estamos diante de questões da recepção: é o problema do texto, sua recepção e as suas possíveis prefigurações que se põem em jogo.

Na natureza, o carrapicho não se fecha sob o risco do toque, do acidente, como o ouriço-animal. Mantém permanentemente seus "signos agudos" para fora. O poema-carrapicho de Siscar faz esse movimento de apontar para fora, que é outro nome dado ao endereçamento. Está sempre nessa fricção com o que vem de fora, sempre a possibilidade de grudar na pele do outro. Porém, uma possibilidade que joga com o segredo que pode estar guardado no excesso de palavras geradoras de silêncio, cujo estado pode ser, no entanto, violado a qualquer instante: "não há silêncio que não se traia."; é o que lemos no primeiro poema de Interior via satélite, "Ficção de início". Nas duas últimas estrofes, novamente, a imagem antitética vem desfazer o fenômeno natural. Como em "O espelho da pele", embaralha-se a diferença entre o interior e o exterior do carrapicho, que, sem intervalo, fecha-se sobre si e oferece-se ao outro. O carrapicho,

${ }^{4}$ Esse poema, publicado na Revista Pessoa - revista de literatura lusófona, em março de 2015, fará parte do novo livro de poemas de Siscar, previsto para setembro deste ano. Disponível: http://www.revistapessoa.com/2015/03/o-espelho-da-pele/ Acesso: 10 de julho de 2015 .

${ }^{5}$ Imagens dessas obras podem ser vistas no livro Adriana Varejão: entre carnes e ares = betweenfleshandoceans. (org. Izabel Diegues; versão para o inglês Stephen Berg). Rio de Janeiro: Cobogó, 2009. 
como o ouriço de Derrida, perde sua potência metafórica e passa a ser uma planta catacrética; é uma planta-poema:

(silêncio) o silêncio diz

você não reclama não pede não aceita não fica não arreda o pé. o interior se

fecha se oferece. carrapicho áspera misericórdia. (SISCAR, 2010a, p. 17)

Um poema-carrapicho que espalha em todo seu corpo, pela força disseminadora do silêncio, a prova do segredo. E aí, é preciso explorar como se conjuga nos poemas de Siscar o direito ao segredo. Não se trata de um segredo que é controlado pela auctoritas do poeta que dissemina em seu corpus lugares secretos a serem explorados ou constrói labirintos para o percurso constituir-se na busca por uma saída. É um "segredo ostentado", para usar a expressão de Derrida. Embora haja cálculo, como em toda poética (carrapichos e corações, assim como silêncios, não brotam naturalmente), tenta-se ao mesmo tempo não fazer um programa e, mesmo, frustrar o programa. Por isso, o silêncio ultrapassa a ideia de tema, de conteúdo, faz parte da experiência do rumor, funcionando como um ciciar que põe no coração dessa poética a questão do segredo, que não é um segredo da técnica, que não se refere à ideia de desvendamento, mas, sim, à reivindicação de pôr em dúvida a eficiência do dizer. E mais, que faz do poema o lugar de recusa do dizer, tal como é sobreditado pelas leis da mensagem. Não há uma mensagem poética, nem mesmo criptografada.

Nesse sentido, é preciso modular o discurso de que se trata de uma poesia difícil, embora não faça parte de uma linhagem poética que usa a aproximação com a prosa para dar forma à relação com o leitor. Como sugeri anteriormente, ovocabulário sobre o interior e o exterior diz respeito também aos modos como nos acostumamos a pensar acerca de duas subjetividades que geralmente norteiam o poema: a do poeta e do leitor. Relaciona-se o autor à intenção e o leitor à interpretação, instituindo-se o desinteresse pelo primeiro e a primazia do segundo. Entretanto, seria preciso investigar o quanto essas categorias não precisam necessariamente ser pensadas dessa maneira em poéticas como a de Siscar, em que se dramatiza a posição desses lugares, isto é, na qual ora se põe em cena o autor, ora o leitor, de modo que não se localiza tão facilmente onde estão a intenção e a interpretação. Como afirma Derrida (1995, p. 42), "o estar-aí do segredo não concerne mais ao privado do que ao público. Não é uma interioridade privada que seria preciso desvendar, confessar, declarar, isto é, pela qual seria preciso responder ao prestar contas e tematizar às 
claras”. Não há revelação a ser feita pelo autor nem delação pelo leitor, pois o modo como se coloca em primeiro plano a questão da obliquidade das referências já constitui um corpus aberto à alteridade; isto é, não é possível demarcar mais do que algumas previsões de leitura, que podem se abrir para campos insuspeitados. Essa abertura para o exterior se dá pela suspensão da ideia de origem.

Nos poemas, o interesse particular pela investigação dos espaços pessoais do poeta, por exemplo, não tem relação com a apropriação de um discurso sobre a vida que estaria nos poemas sem mediação. Em “Sabia?", quando espalha biografemas de Mozart, Pessoa e Cabral, em tom de especulação, o uso da primeira pessoa insere mais do que o eu-lírico; é o nome próprio que entra na série dos outros nomes: “... não interprete agora marcos/ nesta voz que lhe fala só o sabiá assobia” (2010a, p. 72). No entanto, em seu nome, interrompe-se o tom especulativo, barrando a interpretação (ou superinterpretação) da exposição da intimidade que hoje se estende por todos os campos. Por outro lado, em sua relação com o segredo da intimidade, no poema, não pode ser mais do que a história do seu drama. Se não é “interpretável” ou, ainda, se não deveria ter lugar no poema, talvez não seja pelas razões comumenteapontadas, irmanadas com o ideário de eficiência poética que obrigatoriamente impõe o afastamento da subjetividade do poeta. Utilizar-se dos binômios vida/obra, origem/ fins, interior/ exterior, objetividade/ subjetividade parece ser um modo equivocado de pensar a questão. As marcas da vivência do poeta, que servem a especulações biográficas determinadas pela ingenuidade da crença na origem, parecem justamente barrar tal crença, como na última frase de "Pietà": "minha intimidade é o nosso carrapicho" (2010a, p. 99).

A opção pelo "eu" indeciso entre a existência autobiográfica e poética gera um curto-circuito na medida em que nada revela, jogando com essa indeterminação por meio da distribuição aparentemente aleatória de "arquivos pessoais" em seus poemas, sem configurar uma poética sentimental, organizada pelo autobiográfico, pela circunstancialidade do cotidiano ou mesmo uma poesia que extrapola seus limites e intenta ser outra coisa; por exemplo, prosa. Mesmo em $O$ roubo do silêncio, com a totalidade dos poemas em prosa, tudo acontece no poema; isto é, são questões que tocam à poesia e suas possibilidades temáticas e formais.

Na problemática de um possível esvaziamento das questões próprias da literatura que sempre se junta à discussão acerca da inserção do autobiográfico, parece interessar a esse poeta redobrar o espaço do segredo, 
apontando como parte da constituição do poema o que lhe é ditado como estranho ou intruso. "Poema de circunstância", constituído de marcas temporais e espaciais explícitas, é exemplar desse efeito: "22:01 21ํㄷ 22-052008/ lua ao vento leste azul quase perfeito/ argonautas cerveja maré alta/ deseja salvar as alterações?/ arquivo são josé do rio preto" (2010a, p. 46). É a prova de que nenhum contexto dá conta de especificar todos os sentidos, mas também de que não se deve prescindir dele. Nem a referência a São José do Rio Preto, cidade em que o poeta morou durante vários anos, é a prova de ser um texto autobiográfico. É um arquivo - e como tal, portador de memória, mas uma memória que não delata, que não cumpre a função de confessar nenhuma intimidade.

Isso reforça a ideia de que o "eu", que por diversas vezes ocupa mais de um lugar nos poemas, entre o eu-lírico e o eu-biográfico, não lança os poemas em direção ao autobiográfico, mas, sim, às discussões sobre o autobiográfico, o que muda tudo. Como afirma Derrida (1995, p. 61), em uma de suas notas de rodapé, "Quanto ao segredo exemplar da literatura, ...[a]lguma coisa da literatura terá começado quando já não houver sido possível decidir-se, quando falo de qualquer coisa ... ou quando dou um exemplo.... Esse é um dos segredos dos quais só podemos lançar hipóteses como as feitas aqui. É nesse sentido que no segredo não se trataria de interioridade versus exterioridade, de intimidade versus exposição. $\mathrm{O}$ carrapicho que gruda na pele pode também sair de dentro (lembremos do poema). O coração não é uma metáfora do amor (embora possa ser), mas um músculo. E quem diz isso é o poema.

A força ostentatória do segredo, diz Derrida, permite-nos falar dele incessantemente, inventar histórias, encadeá-las e desencadeá-las, sem necessariamente tocá-lo. Essa é a cena que possibilita o poema. A força de interpretação que pode tanto estar com o autor quanto com o leitor não esgota o que está dito; trabalha-se, portanto, no interstício do que é lançado e do que se consegue agarrar, o que, por sua vez, desobriga o poema - e por que não o poeta? - de prestar contas. São duas instâncias que se locupletam, o poeta e o intérprete, sem que saibamos quem diz o quê; afinal, quanto, em uma crítica, advém do repertório do autor, do leitor ou de ambos?

O célebre poema Guardar, de Antônio Cícero enfeixa boa parte das discussões intentadas aqui: "Guardar uma coisa não é escondê-la ou trancá-la/ (...) Guardar uma coisa é escondê-la, fitá-la, mirá-la por/ admirá-la, isto é, iluminá-la ou ser por ela iluminado" (1997, p. 11). Nesses 
versos, também desgarrados de seu corpo integral, reside algo essencial para as hipóteses levantadas. O segredo ostentado da literatura não é uma essência, pois precisa ser posto em jogo a cada vez. O segredo que está guardado, mas não escondido ou trancado, como uma prova do "já-estarali do sentido", desvela-se a partir do olhar do outro; não o de qualquer outro, mas, sim, daquele que se interessa por iluminar e ser iluminado por esse “já-estar-ali”. Não é uma mirada qualquer, mas uma mirada provocada pelo afeto. Em outros termos, tal é a língua da poesia de Siscar; uma língua que empresta um tom à poesia obrigando-a a relançar-se sobre a própria forma sem trancá-la apenas nos aspectos formais. De um a outro livro, essa língua se presta a experimentar maneiras de dizer que não renunciam ao suplemento do silêncio e também a experimentar maneiras de silêncio que não renunciam ao suplemento do dizer. No último poema de Interior via satélite, "Modo de usar", o poema diz o que o poeta não é. E com os últimos versos - "sinto falta da desigualdade. Viro a página e lá estamos/ de novo sós" (2010a, p. 102) - sugere que a solidão não é a de um único sujeito. Mais de um está implicado no "estamos de novo sós”. É provável que esse $a$-mais seja aquele que se interesse por iluminar e ser iluminado pelo poema.

\section{REFERÊNCIAS BIBLIOGRÁFICAS}

BARTHES, Roland. O rumor da língua. Trad. M. Laranjeira. São Paulo: Martins Fontes, 2004.

BARTHES, Roland. Roland Barthes por Roland Barthes. Trad. L. Perrone-Moisés. São Paulo: Estação Liberdade, 2003.

BAUDELAIRE, Charles. O pintor da vida moderna. Trad. T. Tadeu. Belo Horizonte: Autêntica Editora, 2010.

CICERO, Antonio. Guardar: poemas escolhidos. Rio de Janeiro/ São Paulo: Editora Record, 1997.

DERRIDA, Jacques. Paixões. Trad. L. Z. Machado. Campinas: Papirus, 1995.

DERRIDA, Jacques. Che cos'èla poesia?(1992), Trad. T. Rios; M. Siscar. In: Inimigo rumor n. 10. Editora 7 letras, maio de 2001, Rio de Janeiro - Brasil, p. 113-116.

DIEGUES, Izabel (org.). Adriana Varejão: entre carnes e mares. Versão inglês: S. Berg. Rio de Janeiro: Cobogó, 2009. 
GREENAWAY, Peter. O livro de cabeceira (filme). Distribuidora: Europa Filmes, 1996.

LEMOS, Masé. Marcos Siscar por Masé Lemos. Rio de Janeiro: EDUERJ, 2011.

MALUFE, Annita Costa. Poéticas da imanência: Ana Cristina Cesar e Marcos Siscar. Rio de Janeiro: 7 Letras/ Fapesp, 2011.

MELVILLE, Herman. Bartleby, o escrivão: uma história de Wall Street. Trad. I. Hirsch. São Paulo: Cosac Naify, 2005.

PEDROSA, Celia. Poesia, crítica, endereçamento. In: KIFFER, A.; GARRAMUÑO, Florencia. Expansões contemporâneas: literatura e outras formas. Belo Horizonte: Editora UFMG, 2014.

RANCIÈRE, Jacques. A superfície do designe. In: O destino das imagens. Trad. M. C. Netto. Rio de Janeiro: Contraponto, 2012.

SISCAR, Marcos. Metade da arte. São Paulo: Cosac Naify; Rio de Janeiro: 7 Letras, 2003.

SISCAR, Marcos. O roubo do silêncio. Rio de Janeiro: 7 Letras, 2006.

SISCAR, Marcos. Interior via satélite. São Paulo: Ateliê Editorial, 2010a.

SISCAR, Marcos. “Por que escreve?". Remate de Males. Campinas, SP: n. 30, vol. 2, $2010 \mathrm{~b}$.

SISCAR, Marcos. Poesia e crise: ensaios sobre a "crise da poesia" como topos da modernidade. Campinas: SP: Editora da Unicamp, 2010c.

SISCAR, Marcos. Ana Cristina Cesar. Rio de Janeiro: Eduerj, 2011.

SISCAR, Marcos. Da soberba da poesia: distinção, elite, democracia. São Paulo: Lumme Editor, 2012a.

SISCAR, Marcos. Jacques Derrida: literatura, política e tradução. Campinas, SP: Autores associados, 2012b.

SISCAR, Marcos. Manual de flutuação para amadores. Rio de Janeiro: 7 Letras, 2015.

THOMPSON, Frank Chaves. Bíblia de referência Thompson. São Paulo: Editora Vida, 1999. 